University of Nebraska - Lincoln

DigitalCommons@University of Nebraska - Lincoln

8-2003

\title{
Spatial Heterogeneity, Not Visitation Bias, Dominates Variation in Herbivory
}

\author{
Kate L. Bradley \\ University of Nebraska - Lincoln, kbradle1@bigred.unl.edu \\ Ellen I. Damschen \\ North Carolina State University, damschen@wisc.edu \\ Lauren M. Young \\ University of Nebraska - Lincoln \\ Daniel Kuefler \\ North Carolina State University \\ Sarah Went \\ University of Nebraska - Lincoln \\ See next page for additional authors
}

Follow this and additional works at: https://digitalcommons.unl.edu/bioscifacpub

Part of the Life Sciences Commons

Bradley, Kate L.; Damschen, Ellen I.; Young, Lauren M.; Kuefler, Daniel; Went, Sarah; Wray, Galen; Haddad, Nick M.; Knops, Johannes M. H.; and Louda, Svata M., "Spatial Heterogeneity, Not Visitation Bias, Dominates Variation in Herbivory" (2003). Faculty Publications in the Biological Sciences. 59.

https://digitalcommons.unl.edu/bioscifacpub/59

This Article is brought to you for free and open access by the Papers in the Biological Sciences at DigitalCommons@University of Nebraska - Lincoln. It has been accepted for inclusion in Faculty Publications in the Biological Sciences by an authorized administrator of DigitalCommons@University of Nebraska - Lincoln. 


\section{Authors}

Kate L. Bradley, Ellen I. Damschen, Lauren M. Young, Daniel Kuefler, Sarah Went, Galen Wray, Nick M. Haddad, Johannes M. H. Knops, and Svata M. Louda 


\title{
SPATIAL HETEROGENEITY, NOT VISITATION BIAS, DOMINATES VARIATION IN HERBIVORY
}

\author{
Kate L. Bradley, ${ }^{1,3}$ Ellen I. Damschen, ${ }^{2}$ Lauren M. Young, ${ }^{1}$ Daniel Kuefler, ${ }^{2}$ Sarah Went, ${ }^{1}$ \\ Galen Wray, ${ }^{1}$ Nick M. Haddad, ${ }^{2}$ Johannes M. H. Knops, ${ }^{1}$ and Svata M. Louda ${ }^{1}$ \\ ${ }^{1}$ Department of Biological Sciences, University of Nebraska, Lincoln, Nebraska 68508 USA \\ ${ }^{2}$ Department of Zoology, North Carolina State University, North Carolina 27695 USA
}

\begin{abstract}
Experiments in ecology can have unintended side effects. Recently, it has been suggested that the act of visiting a plant, inherent to studying herbivory, may alter plant performance and interactions. To evaluate the generality of this inference, we examined plant performance and herbivory on 14 plant species in three geographic regions. Visitation did not significantly affect any of the variables that we measured, including leaf damage, height, biomass, or survivorship, for any species. However, rates of herbivory varied significantly among sites and regions. Thus, our data do not support the generality of visitation impacting estimates of herbivory. We propose that future studies of herbivory will gain more by evaluating spatial heterogeneity in interaction outcomes than by quantifying possible experimenter-caused variation.
\end{abstract}

Key words: herbivory; herbivory uncertainty principle; observer effect; plant performance; spatial heterogeneity; visitation effect.

\section{INTRODUCTION}

Recently, it has been suggested that visiting a plant to measure herbivory can actually alter herbivory rates and, therefore, bias experimental outcomes (Cahill et al. 2001, 2002, Schnitzer et al. 2002, Hik et al. 2003). If the hypothesis suggested by Cahill et al. (2001, 2002) is true, then the possibility of visitation bias could challenge a substantial body of literature on herbivory. This challenge to the methods used to assess an important biological interaction is not unique to studies of herbivory. Observer bias has been posed as a problem in other ecological systems (Hairston 1989), including studies involving bird nestling survival and predation (Rotella et al. 2000, Verboven et al. 2001, Marshall et al. 2002) and vertebrate seed removal (Duncan et al. 2002, Wenny 2002). Quantitative analyses of such potential biases are critical in order to draw conclusions about their biological significance.

To examine the effects of visitation when assessing herbivory, Cahill et al. (2001) conducted an eight-week experiment involving six species in an old field in southeastern Pennsylvania, USA. Half of the experimental plants were visited and touched each week, whereas half were not visited. Visitation did not significantly alter herbivory for four species, but it did

Manuscript received 10 June 2002; revised 27 October 2002; accepted 22 November 2002. Corresponding Editor: S. Lavorel.

${ }^{3}$ E-mail: kbradle1@ bigred.unl.edu result in decreased leaf damage for one non-native species, Potentilla recta, and increased leaf damage in another, Apocynum cannabinum. Survivorship was not significantly influenced for any species.

Based on these results, Cahill et al. (2001) argued that visitation could have unintended impacts. First, visiting plants causes trampling of nearby plants, which could make them more apparent to herbivores. Trampling nearby plants could also increase light intensity or change the spectral distribution of light, influencing plant competition (Ballaré et al. 1990). Second, human scents left on plants could attract or repel herbivores (Duncan et al. 2002, Wenny 2002). For example, in Wenny's (2002) examination of seed removal by rodents, seeds with human scent were removed more frequently than seeds without human scent. Third, visiting plants could increase or decrease the release of volatile chemicals that attract or repel herbivores. Nevertheless, the release of volatile chemicals from visitation might be of little importance relative to the effects of other stimuli such as wind (Cipollini 1997). Finally, visitation might cause changes in the composition of the herbivore community. If such alterations are common, it may be important to control for visitation effects in experimental design by adding a nonvisitation treatment. However, given the limited body of literature on this issue (Cahill et al. 2001, 2002, Schnitzer et al. 2002, Hik et al. 2003), the generality of a visitation effect has yet to be determined. Here we extend the 


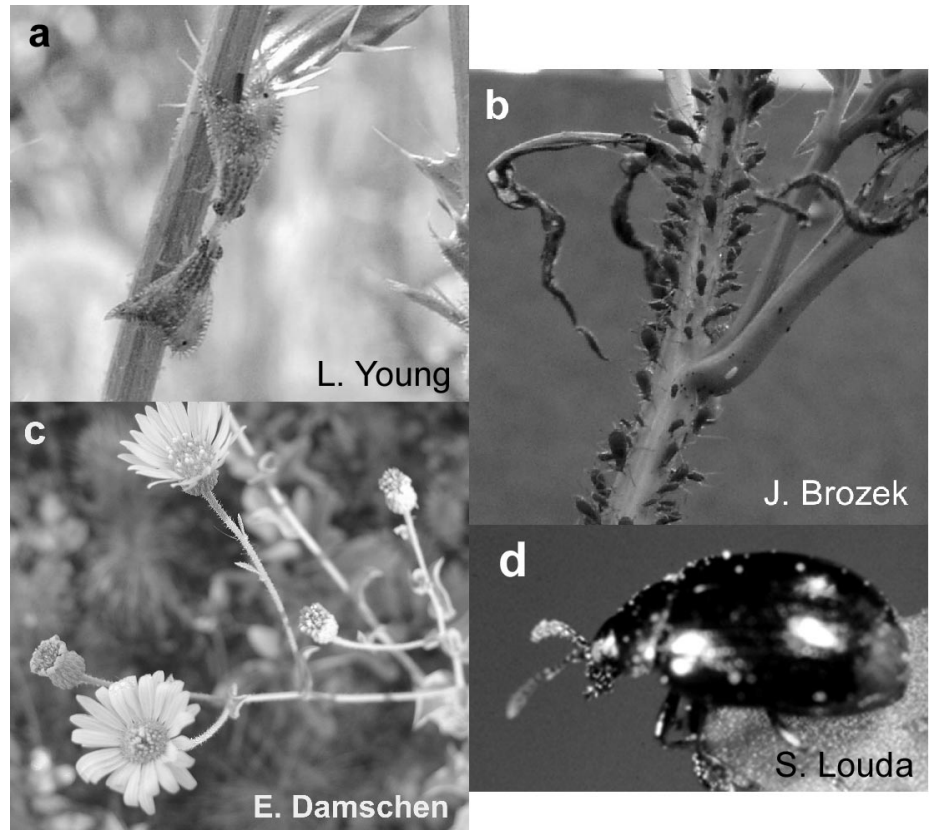

Plate 1. Plant species which were found to have significant site differences in herbivory, and some known herbivores. (a) Cirsium altissimum stem with tephrid flies; (b) Helianthis grosseratus and aphids; (c) Croptilion divaricatum; and (d) C. altissimum with a chrysomelid beetle.

data on visitation effects, using the same methods as Cahill et al. (2001), by focusing on three geographic regions and examining five species at multiple sites within each region. Our results support and extend the challenge by Schnitzer et al. (2002) to the generality of significant visitation effects.

\section{Methods \\ Experimental methods}

The experiment was conducted in grasslands of three states: Minnesota, Nebraska, and South Carolina, USA. Within each state, five plant species that were common enough to study were identified. In total, 14 different species representing six families were used for the entire study (See Table 1). All species except Potentilla recta are native. All except Croptilion divaricatum are perennial. All species except Tephrosia florida have an upright growth pattern. Species were located in at least two different sites, which were spatially separated by at least $800 \mathrm{~m}$ and up to $75 \mathrm{~km}$. Based on species morphology, the individual stems, ramets, or entire plants were randomly chosen, assigned to a treatment group, and then uniformly numbered with aluminum tags; flags were placed $1 \mathrm{~m}$ away to facilitate relocation. Individuals from different treatments were separated by at least $5 \mathrm{~m}$.

Our intention was to test for any visitation effects after the initial designation of study plants, as was done by Cahill et al. (2001). Therefore, half of the experimental individuals at each site were randomly selected for the visitation treatment after initial measurement. The treatment entailed weekly visitations modeled after those of Cahill et al. (2001), in which plants were approached and touched once from the base to the tip, such contact as that imposed by frequent measurements of herbivory (see Plate 1). In the control treatment, individuals were left unvisited, after their initial selection, during the experiment. Initial measurements of experimental plants included height, total number of leaves, number of leaves damaged, and whether plant damage was due to vertebrate or invertebrate herbivory. Plant height was defined as the distance between the base of the plant at ground level and the apical meristem. Additional measurements were made in two states. In Minnesota, the proportion of leaf area damaged was estimated. In Nebraska, the proportion of aboveground plant organs damaged was determined. Additionally, for Cirsium altissimum in Nebraska, we counted the number of damaged heads and buds and estimated the proportion of insect-damaged seed. Dates of initial measurements in 2001 were 7 June in Minnesota, 11 June in Nebraska, and 19 June in South Carolina. The experiment was ended eight weeks later, in mid-August. Measurements were taken at the end for all plants, and survivorship was recorded. All individuals were harvested at the root crown, dried to 
TABLE 1. $F$ values from Type III GLM analyses are given for the proportion of leaves damaged, final height, final aboveground biomass, leaf area damaged, and proportion of plant organs damaged as a function of visitation treatment (Trt) as a fixed effect, site $(\mathrm{S})$ as a random effect, and their interaction $(\mathrm{T} \times \mathrm{S})$.

\begin{tabular}{|c|c|c|c|c|c|c|c|}
\hline \multirow[b]{2}{*}{ Species, by state } & \multirow{2}{*}{$\begin{array}{l}\text { Error } \\
\text { df }\end{array}$} & \multicolumn{3}{|c|}{$\begin{array}{l}\text { Proportion of total } \\
\text { leaves damaged }\end{array}$} & \multicolumn{3}{|c|}{ Final height } \\
\hline & & Trt & Site & $\mathrm{T} \times \mathrm{S}$ & Trt & Site & $\mathrm{T} \times \mathrm{S}$ \\
\hline \multicolumn{8}{|l|}{ Minnesota } \\
\hline Artemesia ludoviciana & 66 & 0.5 & 5.4 & 4.5 & 0.2 & 1.1 & 5.8 \\
\hline Lespedeza capitata & 65 & 3.0 & 0.0 & 1.7 & 0.8 & 1.3 & 2.1 \\
\hline Potentilla recta & 60 & 1.9 & 7.4 & 1.4 & 32.4 & 3.8 & 0.8 \\
\hline Rhus glabra & 61 & 0.5 & 0.6 & 1.8 & 8.1 & 7.4 & 0.7 \\
\hline Solidago gigantea & 66 & 14.0 & 13.4 & 0.8 & 1.9 & 2.3 & 5.5 \\
\hline \multicolumn{8}{|l|}{ Nebraska } \\
\hline Asclepias syriaca & 26 & 13.2 & 2.6 & 0.1 & 1.3 & 4.2 & 0.7 \\
\hline Cirsium altissimum & 47 & 1.0 & 22.1 & 0.3 & 0.0 & 3.2 & 3.8 \\
\hline Helianthus grosserratus & 51 & 0.2 & 42.3 & 0.8 & 0.2 & 58.2 & 0.1 \\
\hline Rhus glabra & 55 & 1.0 & 1.0 & 1.0 & 0.1 & 0.1 & 7.5 \\
\hline Solidago altissima & 55 & 0.4 & 0.3 & 4.4 & 2.5 & 0.4 & 0.3 \\
\hline \multicolumn{8}{|l|}{ South Carolina } \\
\hline Croptilion divaricatum & 56 & 0.5 & 0.2 & 14.1 & 1.0 & 0.5 & 3.3 \\
\hline Tephrosia florida & 56 & 0.6 & 97.3 & 8.4 & 0.1 & 2.6 & 0.2 \\
\hline Rhus copallina & 56 & 0.1 & 1.0 & 1.1 & 0.0 & 10.0 & 0.1 \\
\hline Lespedeza stuevei & 52 & 6.1 & 4.1 & 0.1 & 2.8 & 7.4 & 5.3 \\
\hline Phytolacca americana & 56 & 0.0 & 0.1 & 2.6 & 0.6 & 15.5 & 0.2 \\
\hline
\end{tabular}

Notes: Boldface $F$ values are significant at $\alpha=0.05$ (Bonferroni correction for multiple comparisons, adjusted $P<0.0009$ ). For all comparisons, numerator $\mathrm{df}=1$, except for the Artemesia site and $\mathrm{T} \times \mathrm{S}(\mathrm{df}=2)$. The denominator $\mathrm{df}=1$ for treatment comparisons. The error df values are listed in the table.

constant mass, and weighed to obtain aboveground biomass.

\section{Sites}

Savannah River Site, South Carolina.-At the Savannah River Site, a National Environmental Research park, plants were studied in two early-successional fields. These sites are managed by the U.S. Forest Service for timber production and were created by harvesting Pinus spp. in 1999 and then planting Pinus palustris. In each site, individuals were randomly selected and assigned to a treatment. Species used were: Croptilion divaricatum, Lespedeza stuevei, Phytolacca americana, Rhus copallina, and Tephrosia florida. At Site $1, N=10$ individuals per species for each treatment; at Site 2, $N=20$ individuals per treatment. Although there was some mortality, we were able to make necessary measurements on all individuals at the end of the experiment. Plant height for Tephrosia florida, a procumbent species, was measured as the distance between the rooting stems and its longest creeping stem when pulled taut.

Reller Ranch and Madigan Prairie, Nebraska.-In Nebraska, plants were studied at Reller Ranch in Lancaster County and at Madigan Prairie in Saunders County. Both sites were a mixture of open tallgrass prairie with smaller wooded areas. Species used were Asclepias syriaca, Cirsium altissimum, Helianthus grosserratus, Rhus glabra, and Solidago altissima.
Thirty individuals of each species were randomly selected over 2 acres ( 0.8 ha) at each site. Another randomization was used to assign treatments $(N=15$ for each species per site and per treatment). Mortality reduced sample sizes for final measurements as follows ( $N_{\text {control }}$ and $N_{\text {visited, }}$, respectively): Madigan Prairie, $A$. syriaca $(8,9), C$. altissimum $(15,14), H$. grosserratus $(14,14), R$. glabra $(14,15)$, and $S$. altissima $(15,15)$; Reller Ranch, A. syriaca $(6,7), C$. altissimum $(11,13)$, $H$. grosserratus $(12,15), R$. glabra $(15,15)$, and $S$. altissima $(14,15)$. To avoid clonal influence, individual ramets of $S$. altissima were selected from 30 separate clonal patches at each site.

Cedar Creek Natural History Area, Minnesota.-In Minnesota, plants were studied in six early- to midsuccessional grassland fields at Cedar Creek Natural History Area, $45 \mathrm{~km}$ north of Minneapolis-St. Paul, Minnesota, USA. Field 29 was small and surrounded by pine trees, and had dense, $1.5 \mathrm{~m}$ tall vegetation. Field B was more open, with very short vegetation. Field 71 was located close to a rural road and had full sun exposure. Field 84A was located next to a deciduous tree line. Field 84 was an open field with grassy $1 \mathrm{~m}$ high vegetation. Field 85 had vegetation 30-50 $\mathrm{cm}$ high. For details on these individual fields, see Inouye et al. (1987).

Species included were Artemesia ludoviciana, Lespedeza capitata, Potentilla recta, Rhus glabra, and Solidago gigantea. Seventy-two individuals of each spe- 
TABLE 1. Extended.

\begin{tabular}{|c|c|c|c|c|c|c|c|c|}
\hline \multicolumn{3}{|c|}{$\begin{array}{c}\text { Final aboveground } \\
\text { biomass }\end{array}$} & \multicolumn{3}{|c|}{$\begin{array}{c}\text { Proportion of } \\
\text { leaf area damaged }\end{array}$} & \multicolumn{3}{|c|}{$\begin{array}{c}\text { Proportion of plant } \\
\text { organs damaged }\end{array}$} \\
\hline Trt & Site & $\mathrm{T} \times \mathrm{S}$ & Trt & Site & $\mathrm{T} \times \mathrm{S}$ & Trt & Site & $\mathrm{T} \times \mathrm{S}$ \\
\hline 0.5 & 1.8 & 4.3 & 0.4 & 2.0 & 7.2 & \multirow{5}{*}{\multicolumn{3}{|c|}{ not measured }} \\
\hline 0.6 & 0.1 & 0.5 & 2.5 & 0.1 & 1.0 & & & \\
\hline 22.9 & 5.3 & 0.3 & 0.0 & 0.3 & 2.0 & & & \\
\hline 2.1 & 4.2 & 0.3 & 1.0 & 4.1 & 1.8 & & & \\
\hline 0.2 & 1.4 & 2.9 & 0.9 & 0.3 & 2.6 & & & \\
\hline 22.6 & 8.5 & 0.0 & \multirow{5}{*}{\multicolumn{3}{|c|}{ not measured }} & 0.0 & 0.1 & 0.3 \\
\hline 10.1 & 6.9 & 0.2 & & & & 49.4 & 8.7 & 0.1 \\
\hline 1.8 & 15.4 & 0.3 & & & & 1.3 & 0.2 & 0.6 \\
\hline 0.3 & 2.1 & 4.0 & & & & 5.0 & 0.4 & 0.5 \\
\hline 1.4 & 6.0 & 2.1 & & & & 0.6 & 4.0 & 2.6 \\
\hline 48.7 & 0.6 & 0.1 & \multirow{5}{*}{\multicolumn{3}{|c|}{ not measured }} & \multirow{5}{*}{\multicolumn{3}{|c|}{ not measured }} \\
\hline 100 & 5.1 & 0.3 & & & & & & \\
\hline 4.1 & 10.7 & 0.2 & & & & & & \\
\hline 5.1 & 4.5 & 0.0 & & & & & & \\
\hline 0.1 & 11.2 & 1.0 & & & & & & \\
\hline
\end{tabular}

cies were randomly selected and randomly assigned a treatment (initially, $N=36$ plants per species per treatment). Mortality reduced final sample sizes as follows ( $N_{\text {control }}$ and $N_{\text {visited }}$, respectively): Field 71, A. ludoviciana $(18,17)$ and $S$. gigantea $(24,23)$; Field $84, S$. gigantea $(10,12)$; Field 84A, A. ludoviciana $(12,12)$, R. glabra $(12,11)$, and L. capitata $(30,28)$; Field 85, A. ludoviciana $(6,6), R$. glabra $(22,22)$, and L. capitata $(6,6)$; Field 29, P. recta $(11,9)$; Field B, P. recta $(22$, $20)$. The $S$. gigantea ramets in Field 84 belonged to one clone, and ramets in Field 71 belonged to another clone.

\section{Statistical analyses}

To analyze responses, we used Type III GLMs. These were performed for each species in each state. The visitation treatment was designated a fixed effect, whereas site was designated as a random effect (Underwood 1997). We examined the impact of the fixed effect of visitation on the following variables: proportion of leaves damaged, plant height (in centimeters) at the final visit, and aboveground biomass (grams) at the final visit. In addition, we calculated the proportion of plant organs damaged, leaf area damaged, damaged heads and buds, and insect-damaged seed. We examined both initial heights, which varied among sites, and final aboveground biomass as covariates for our analysis. Because neither influenced the treatment or site effects, the final analyses were done without covariates. In total, 57 comparisons were performed because the species were not the same across geographic regions or found at the same sites within all regions. To limit the experimental error rate, we used the Dunn-Sidák procedure (Sokal and Rohlf 2000), as necessitated by the use of multiple comparisons $(P<0.0009 \sim P<$ $0.05 ; P<0.00018 \sim P<0.01$; and, $P<0.000018 \sim$ $P<0.001)$. All analyses were performed using SPSS 10.1 (Norusis 1990). Prior to analyses, all proportions and percentages were arcsine square-root transformed.

The Wilcoxon signed-ranks test was used to analyze for treatment differences in survivorship (Sokal and Rohlf 2000). Survivorship was calculated as a percentage for each treatment group. Species were paired by treatment, and differences in survivorship were calculated. Differences of zero were removed in the analysis (Sokal and Rohlf 2000). There were only two to three pairs for each species, but the minimum number of pairs required for the test is six. Therefore, the analysis included all species pairs and was performed independent of state.

\section{RESUlts}

Visitation did not have a significant effect on the proportion of leaves damaged, the final plant height, or the final aboveground biomass (Table 1) of any species in Minnesota (Fig. 1a), Nebraska (Fig. 1b), or South Carolina (Fig. 1c). Four additional measures of herbivory, which included leaf area damaged (Minnesota only), proportion of plant organs damaged ( $\mathrm{Ne}$ braska only), the number damaged heads and buds (Nebraska only: $F_{1,1}=1.2$, Cirsium altissimum), and the evidence of insect feeding on Cirsium altissimum seeds 

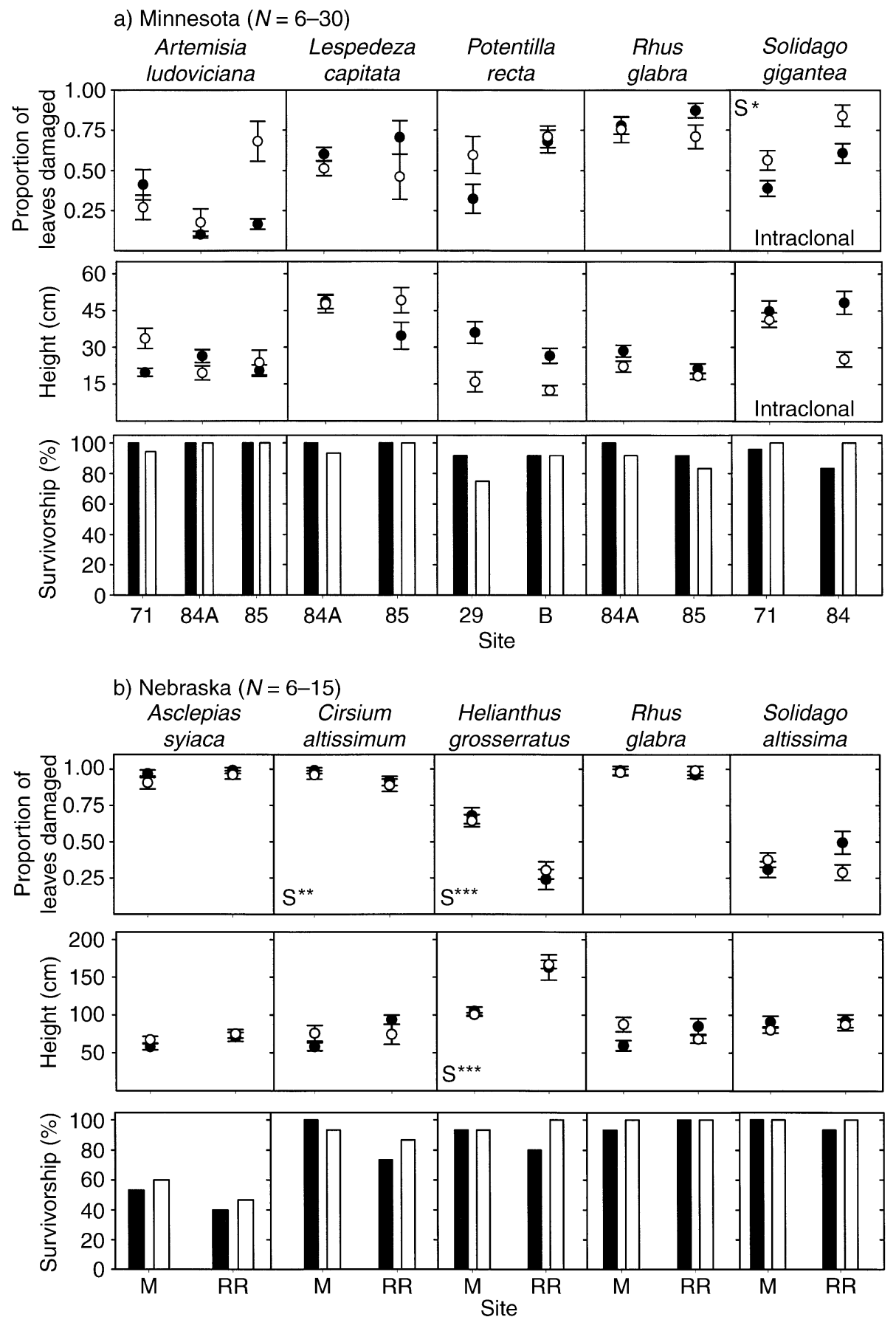

FIG. 1. Proportion of leaves damaged (mean $\pm 1 \mathrm{SE}$ ), final height (mean $\pm 1 \mathrm{SE}$ ), and survivorship of plants as a function of visitation treatment (control, solid circles and bars; visited, open circles and bars) and site. Means were calculated for each species and are based on individuals within a given site, whereas survivorship is given as the percentage of individuals alive at the end of the experiment. For Minnesota and Nebraska, the number of individuals per treatment varied depending on the species and site (see Methods for details); for South Carolina, the number of individuals per treatment varied by site. Significant site differences are denoted by an $\mathrm{S}$, and interactions by $\mathrm{T} \times \mathrm{S}$ (with Bonferroni correction for multiple comparisons [Sokal and Rohlf 2000]): * $P<0.05$; ** $P<0.01$; *** $P<0.001$. No significant treatment effects were found using the Wilcoxon matched-pairs signed ranks test for survivorship (Sokal and Rohlf 2000). 
c) South Carolina (Site 1, $N=10$; Site 2, $N=20$ )

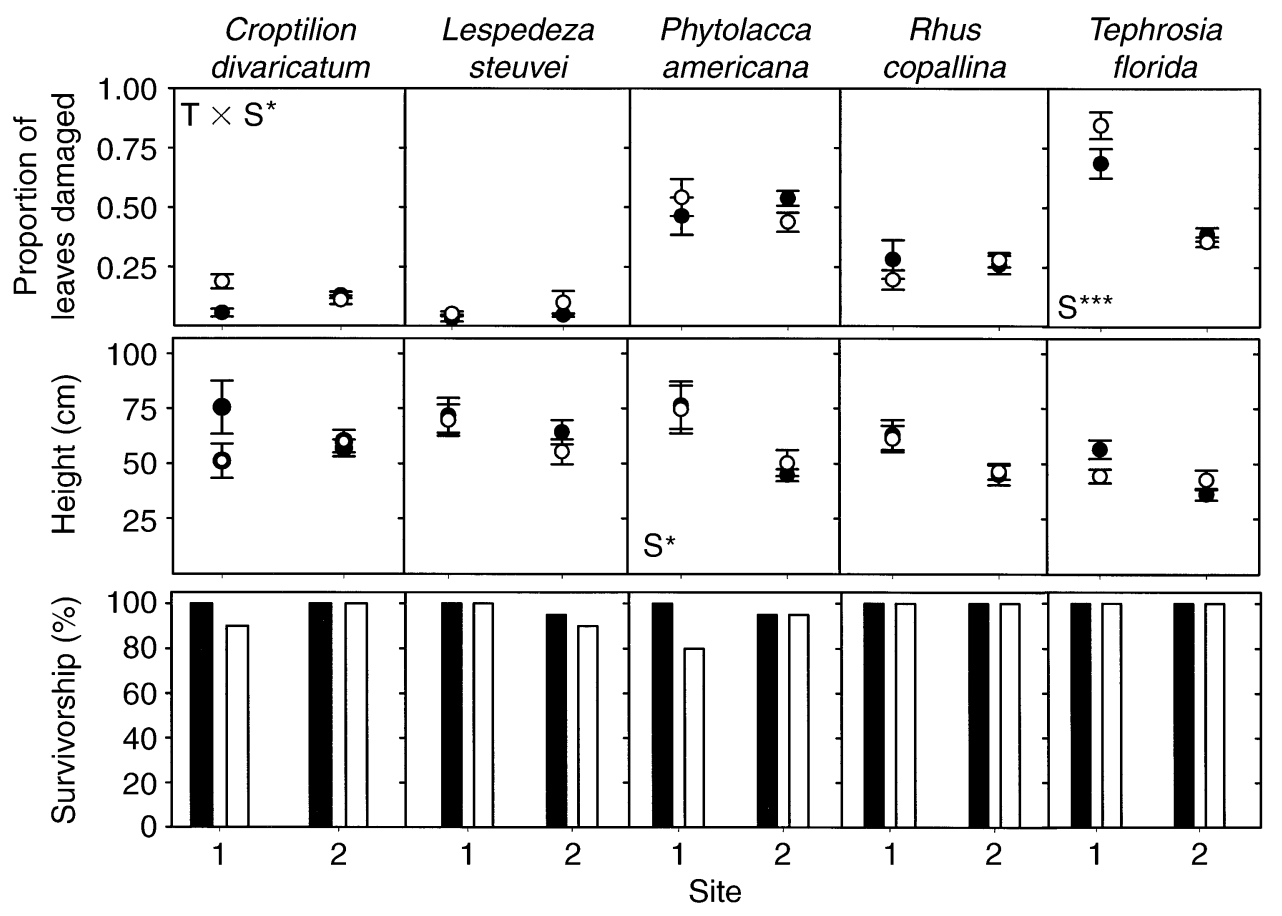

FIG. 1. Continued.

$\left(F_{1,1}=6.2\right)$, were also not influenced by visitation (Table 1). A significant interaction occurred between site and treatment for the proportion of leaves damaged in Croptilion divaricatum (Fig. 1c). Using pre-treatment measurements as a covariate did not alter any of these patterns. Additionally, visitation did not significantly alter the survivorship of any species (Fig. 1a-c; Wilcoxon matched-pairs signed-ranks test: $\mathrm{T}_{\mathrm{s}} \leq \mathrm{T}_{\text {critical }} N=$ $\left.17, \mathrm{~T}_{\text {critical }}=41, \mathrm{~T}_{\mathrm{s}}=71\right)$. The source of mortality for plants was not known, but the lack of difference eliminates the alteration of herbivory by visitation as the cause.

Finally, although it appeared that visited Potentilla recta individuals might be shorter than the unvisited controls (Fig. 1a), the difference was not significant statistically (Table 1). However, we used site as a random factor in our GLM analysis (Underwood 1997, Zar 1999). This requires that the $F$ value for the fixed factor, e.g., the visitation treatment, be calculated by dividing the treatment mean square by the interaction mean square value (Underwood 1997, Zar 1999), and that the $F$ critical value be determined by using the interaction term's corresponding degrees of freedom (Underwood 1997, Zar 1999), which in our case was $\mathrm{df}=1$. Alternatively, using site in a fixed factor requires that the $F$ value be calculated by dividing the treatment mean square by the error mean square value
(Zar 1999), and that the $F$ critical value be determined by using the error term's corresponding degrees of freedom (Zar 1999), which in our case varied from df $=$ 26 to 66 (Table 1). Analyzing the data in this manner resulted in one significant effect after Bonferroni corrections; the final heights of visited $P$. recta individuals were significantly less than those of control plants. Interestingly, all of the remaining $P$. recta plants showed signs of deer herbivory, with the tops of the plants being heavily browsed.

Thus, visitation did not cause a difference in the evidence of feeding by either of the two major categories of herbivores, invertebrates and vertebrates (with the possible exception of $P$. recta), as found by Cahill et al. (2001). Across all of the species, signs of invertebrate herbivory occurred on $82 \%$ of the visited plants and $84 \%$ of the control plants. Signs of vertebrate herbivory occurred on only $11 \%$ of the visited and $10 \%$ of the control plants.

Site differences affected herbivory rates more than did visitation. For example, in Minnesota, Soliago gigantea ramets had a significantly higher proportion of their leaves damaged in Field 84 than in Field 71 (Fig. 1a). In Nebraska, Helianthus grosserratus individuals at Madigan Prairie had significantly more herbivory than those at Reller Ranch (Fig. 1b), and plants were significantly taller at Reller Ranch. Cirsium altissimum 
individuals also experienced higher mortality and significantly lower levels of herbivory at Reller Ranch than at Madigan Prairie (Fig. 1b). In South Carolina, Tephrosia florida individuals were significantly shorter at Site 2 than at Site 1 (Fig. 1c).

\section{DISCUSSION}

Visitation did not significantly affect any of our measurements of plant performance for the 14 species that we examined, supporting recent tests by Schnitzer et al. (2002), who also found no effect of visitation on herbivory. Only one significant treatment by site interaction occurred for the proportion of leaves damaged in Croptilion divaricatum. At Site 1, C. divaricatum individuals had a higher proportion of leaves damaged when visited and were shorter, on average, than unvisited plants (Fig. 1c), whereas at Site 2 we found no difference in the proportion of leaves damaged or height with visitation (Table 1 ). The only potential visitation effect that we observed involved analyzing site as a fixed effect, not a random one. The analysis resulted in visited Potentilla recta individuals being significantly shorter than control plants. Thus, at best, visitation has a minor impact on herbivory estimates.

Interestingly, significant differences in levels of herbivory reflected the spatial heterogeneity within and between sites in the herbivore communities (Wiens 1976, Stanton 1983), rather than visitation effects. Although the data now available do not support strong, widespread visitation effects (Cahill et al. 2001, 2002, Schnitzer et al. 2002, Hik et al. 2003), it is important to consider how human visitation might alter herbivory. Cahill et al. (2001) proposed four general mechanisms by which visitation bias may affect estimates of herbivory. Estimates may be biased if (1) trampling of vegetation changes the visibility of target plants or competitive interactions, (2) human scent left behind alters insect attraction to plants, (3) plant volatile emissions are altered, or (4) herbivore community composition is disturbed. Repeated visits to the plants create paths through the vegetation, potentially making plants more visible and accessible to deer. Other studies suggest that mammals tend to travel on pre-existing paths such as roads or ditches (Clevenger et al. 2001).

The only plant species with responses that might match this potential mechanism is Potentially recta, although the differences that we observed were not statistically significant. A treatment by site interaction for the proportion of leaves damaged in Croptilion divaricatum may have been caused by one of the other mechanisms. It is difficult to rule out the potential that the human scent may influence insect detection of its host plant. Altered emissions are a possibility. Plant responses to herbivory are often inducible, although they typically require highly specific conditions (Tur- lings et al. 1995, Pare et al. 1998), usually triggered by feeding herbivores (Pare et al. 1998). Finally, visitation might cause changes in the composition of the herbivore community on $C$. divaricatum by startling the herbivores or possibly knocking them off the target plant. More important, it is likely that spatial heterogeneity (Louda 1982, 1983, Louda et al. 1990) exists in herbivore community composition and distribution (Wiens 1976, Stanton 1983, Dutilleul 1993, Rand 2002) as well as in plant defenses and quality (Louda and Rodman 1996, Cipollini 1997). More work is required to differentiate the roles of variation in human scent, plant volatiles, and the herbivore community when visitation effects do occur. In summary, what do our results suggest about the measurement of herbivory in the field? They most strongly point to the importance of understanding variation in the herbivore and plant community to explain variation in levels of herbivory in nature.

In order to deal realistically with uncontrolled processes in the environment such as herbivory, Eberhardt and Thomas (1991) argued for the importance of first observing the process, establishing its spatial pattern, and then designing the sampling effort around the observed spatial pattern. Dutilleul (1993) also emphasized the need to quantify existing spatial heterogeneity and to accommodate this variation in the experimental design. Several strategies are available to control variation present in field studies (Eberhardt and Thomas 1991). One strategy is to increase replication at the site level for invertebrate herbivores (Louda and Rodman 1996, Cipollini 1997). Our results support this suggestion. Another approach is to remove extraneous influences during statistical analyses, which implies the use of pre-experimental data in the analysis to control for any initial differences.

The potential for within-site variation (Wiens 1976, Stanton 1983, Dutilleul 1993, Louda and Potvin 1995, Rand 2002), as well as systematic site differences in insect herbivory, have long been recognized (Louda 1982, 1983, Louda et al. 1990). However such important variation in herbivory remains under evaluated (Rand 2002). We conclude that our understanding of the role of herbivory in plant performance and dynamics is more likely compromised by insufficient understanding of patterns in herbivore abundances and interactions associated with plant community variation within and among sites (Rand 2002) than by the visitation bias postulated by Cahill and colleagues (2001).

\section{ACKNOWLEDGMENTS}

We would like to thank J. F. Cahill, Jr., M. J. Crawley, and S. Lavorel for comments on earlier drafts, and the following people for technical and intellectual assistance: W. G. Abrahamson, J. Haarstad, K. H. Keeler, A. Krings, J. Orrock, D. Pilson, T. A. Rand, and T. Wentworth. This research was 
supported by the School of Biological Sciences Special Funds at the University of Nebraska, the USDA Forest Service at the Savannah River Site, North Carolina State University, and National Science Foundation grant DEB 0087206.

\section{Literature Cited}

Ballaré, C. L., A. L. Scopel, and R. A. Sánchez. 1990. Farred radiation reflected from adjacent leaves: an early signal of competition in plant canopies. Science 247:329-332.

Cahill, J. F., Jr., J. P., Castelli, and B. B. Casper. 2001. The herbivory uncertainty principle: visiting plants can alter herbivory. Ecology 82:307-312.

Cahill, J. F., Jr., J. P. Castelli, and B. B. Casper. 2002. Further examination of the herbivory uncertainty principle: separating the effects of visiting and touching plants. American Journal of Botany 89:1401-1409.

Cipollini, D. F. 1997. Wind-induced mechanical stimulation increases pest resistance in common bean. Oecologia 111 84-90

Clevenger, A. P., B. Chruszcz, and K. Gunson. 2001. Drainage culverts as habitat linkages and factors affecting passage by mammals. Journal of Applied Ecology 38:13401349.

Duncan, R. S., D. G. Wenny, M. D. Spritzer, and C. J. Whelan. 2002. Does human scent bias seed removal studies? Ecology 83:2630-2636.

Dutilleul, P. 1993. Spatial heterogeneity and the design of ecological field experiments. Ecology 74:1646-1658.

Eberhardt, L. L., and J. M. Thomas. 1991. Designing environmental field studies. Ecological Monographs 61:53-73.

Hairston, N. G. 1989. Ecological experiments: purpose, design, and execution. Cambridge University Press, Cambridge, UK.

Hik, D. S., M. Brown, A. Dabros, J. Weir, and J. F. Cahill, Jr. 2003. Prevalence and predictability of handling effects on plants in field studies: results from field experiments and a meta-analysis. American Journal of Botany 90:270277

Inouye, R. S., N. J. Huntly, D. Tilman, J. Tester, M. Stillwell, and K. Zinnel. 1987. Old-field succession on a Minnesota sand plain. Ecology 68:12-26.

Louda, S. M. 1982. Distribution ecology: variation in plant recruitment over a gradient in relation to insect seed predation. Ecological Monographs 52:25-41.

Louda, S. M. 1983. Seed predation and seedling mortality in the recruitment of a shrub, Haplopappus venetus (Asteraceae) along a climatic gradient. Ecology 64:511-521.

Louda, S. M., K. H. Keeler, and R. D. Holt. 1990. Herbivore influences on plant performance and competitive interactions. Pages 414-444 in J. B. Grace and D. Tilman, editors. Perspectives on plant competition. Academic Press, San Diego, California, USA.
Louda, S. M., and M. A. Potvin. 1995. Effect of inflorescence-feeding insects on the demography and lifetime fitness of a native plant. Ecology 76:229-245.

Louda, S. M., and J. E. Rodman. 1996. Insect herbivory as a major factor in the shade distribution of a native crucifer (Cardamine cordifolia A. Gray, bittercress). Journal of Ecology 84:229-237.

Marshall, M. R., R. J. Cooper, J. A. DeCecco, J. Strazanac, and L. Butler. 2002. Effects of experimentally reduced prey abundance on the breeding ecology of the Red-eyed Vireo. Ecological Applications 12:261-280.

Norusis, M. J. 1990. SPSS base system user's guide. Version 10.1. SPSS, Chicago, Illinois, USA

Pare, P. W., H. T. Alborn, and J. H. Tumlinson. 1998. Concerted biosynthesis of an insect elicitor of plant volatiles. Proceedings of the National Academy of Sciences (USA) 95: 13971-13975.

Rand, T. A. 2002. Variation in insect herbivory across a salt marsh tidal gradient influences plant survival and distribution. Oecologia 132:549-558.

Rotella, J. J., M. L. Taper, and A. J. Hansen. 2000. Correcting nesting-success estimates for observer effects: maximumlikelihood estimates of daily survival rates with reduced bias. Auk 117:92-109.

Schnitzer, S. A., P. B. Reich, B. Bergner, and W. P. Carson 2002. Herbivore and pathogen damage on grassland and woodland plants: a test of the herbivore uncertainty principle. Ecology Letters 5:531-539.

Sokal, R. R., and F. J. Rohlf. 2000. Biometry. Third edition. W. H. Freeman, New York, New York, USA.

Stanton, M. L. 1983. Spatial patterns in the plant community and their effects upon insect search. Pages 125-157 in S Ahmad, editor. Herbivorous insects: host-seeking behavior and mechanisms. Academic Press, New York, New York, USA.

Turlings, T. C. J., J. H. Loughrin, P. J. McCall, U. S. R. Rose, W. J. Lewis, and J. H. Tumlinson. 1995. How caterpillardamaged plants protect themselves by attracting parasitic wasps. Proceedings of the National Academy of Sciences (USA) 92:4169-4174

Underwood, A. J. 1997. Experiments in ecology: their logical design and interpretation using analysis of variance. Cambridge University Press, Cambridge, UK.

Verboven, N., B. J. Ens, and S. Dechesne. 2001. Effect of investigator disturbance on nest attendance and egg predation in Eurasian oystercatchers. Auk 118:503-508.

Wenny, D. G. 2002. Effects of human handling of seeds on seed removal by rodents. American Midland Naturalist 147: 404-408.

Wiens, J. A. 1976. Population responses to patchy environments. Annual Review of Ecology and Systematics 7:81120

Zar, J. H. 1999. Biostatistical analysis. Fourth edition. Prentice Hall, Upper Saddle River, New Jersey, USA. 